\title{
Why has the relationship between psychiatry and genetics been so contentious?
}

Leon Eisenberg, $M D$

What claim can possibly justify the presence of a social psychiatrist at a meeting of the American Society of Professors of Human or Medical Genetics? There is only one: I am old enough to remember the contentious relationship between genetics and psychiatry. When I entered the field in 1950, ${ }^{1}$ psychiatrists, with rare exceptions, repudiated genetics. Today, genetics is all the rage. Former critics now claim to have been closet geneticists all along. No issue of a major psychiatric journal is complete without several papers on genetics. Why was genetics in such disfavor 50 years ago, and why is it now entrenched so firmly that my colleagues in psychiatry as well as genetics were surprised by my choice of title?

To put the issues in context, I will briefly review the history of past abuse and indicate why I believe that the past is not so far behind us as most imagine. I will then indicate why I believe that genetics must be understood in a developmental framework to fulfill its promise of liberating medicine from typological thinking. ${ }^{2}$ I will do so by telling you stories, true stories about diverse topics: heritability, polyphenisms, gene regulation by parental care, and the unresolved problem of providing effective genetic counseling.

\section{ORIGINS}

Francis Galton, who coined the word "eugenics" in 1883, conceptualized the relationship between nature and nurture as dichotomous and competitive when he wrote:

The phrase "nature and nurture" is a convenient jingle of words for it separates under two distinct heads the innumerable elements of which personality is composed.... When nature and nurture compete for supremacy on equal terms. . the former proves to be the stronger. ${ }^{3}$

Karl Pearson, who invented the correlation coefficient and the chi-square statistic, founded the Annals of Eugenics (renamed the Annals of Human Genetics in 1954). In its very first volume in 1925, Pearson and Moul ${ }^{4}$ asserted that the "welfare of our own country is bound up with the maintenance and improvement of its stock" and lamented the "potentially dysgenic effect" of unchecked Jewish immigration from Russia and Poland on the Anglo-Saxon stock of Great Britain. In the

\footnotetext{
From Harvard Medical School, Boston, Massachusetts.

Presented at the Annual Meeting of the Association of Professors of Human or Medical Genetics, Tucson, Arizona, April 21, 2001.

Leon Eisenberg, Harvard Medical School, 641 Huntington Avenue, Boston, MA 02115.

Received: May 21, 2001.

Accepted: June 5, 2001.
}

United States, the eugenic viewpoint was sufficiently powerful that Congress enacted the Immigration Act of 1924, which sharply reduced the numbers of Eastern and Southern Europeans allowed into the country. President Calvin Coolidge proclaimed that "biological laws show that Nordics deteriorate when mixed with other races." Supreme Court Justice Oliver Wendell Holmes, in a decision upholding the constitutionality of compulsory sterilization, said that "three generations of imbeciles are enough." 5

In his reminiscences, the distinguished Danish psychiatrist Eric Stromgren ${ }^{6}$ commented that in the 1920s and 1930s most academic and asylum psychiatrists in Europe believed that schizophrenia and manic-depressive disorder were inherited. After the war, he reports, attitudes changed strikingly: "genetics had become a dirty word." He could not discuss with most American psychiatrists even "the possibility of a genetic contribution to the etiology."

The widespread antipathy toward genetics reflected revulsion against the way "genetics" had been co-opted to support Nazi ideology. Ernst Rudin, acknowledged to be the founder of psychiatric genetics, wrote that homosexuality is a genetically determined "diseased form of degeneracy" in the first volume of the Archiv fur Rassen-Und Gesellschaftsbiologie in 1904. That same Rudin helped to write the Law for the Prevention of Genetically Diseased Offspring, which the Reichstag passed on July 14, 1933 (the very day Hitler outlawed the formation of political parties). A decade later, for his services to the Third Reich, Rudin received an Adlerschild, an Eagle's Shield medal, as a "pathbreaker in the field of human hereditary care."

All of us can agree that Nazi race theory was egregious irrational nonsense disguised as science. Why do I conjure up such long dead ghosts? Because they aren't so dead. If scientists as distinguished as Galton and Pearson, who are still cited, could have supported such beliefs, then it behooves us to be vigilant against their revival.

\section{GENETICS IN PUBLIC DISCOURSE}

With the hoopla surrounding the Genome Project, genetics as destiny has entered public discourse in ways sometimes humorous but more often not. Garrison Keillor, commenting on the ingathering of a Lake Woebegone family for a traditional Thanksgiving dinner, described the scene as follows:

After a half hour in the living room, all possible topics of conversation had been exhausted. We sat there eyeing each other in silence, hoping against hope genetics isn't everything. 
Pop sociobiology inspired Susan Jacobson, a fund-raiser active in Democratic party politics. She was asked what she thought about the news that the Reverend Jesse Jackson had fathered a child out of wedlock. Eager to defuse the issue, she replied:

I bet if you did a survey of very successful male leaders, we would probably find a disproportionate number who sleep around. If we're going to limit leaders to men who can keep their penises in their pants, then we're going to have no leaders. The gene for screwing around must be the same as the one for great leadership. ${ }^{8}$

Most of the newspaper stories aren't charming at all. Jim Watson, in a campus address at Berkeley, mused about putative biochemical links between skin color and sexual activity and between thinness and ambition. ${ }^{9}$ Watson later backed off and said he was just being provocative. Lighting matches near gasoline is more than provocative. Consider how skin color and sex come together in an allegedly "scientific" theory of " $r / \mathrm{K}$ reproductive strategies" put forward by J.P. Rushton and A.F. Bogaert of the University of British Columbia. ${ }^{10}$ The theory postulates a "trade-off between egg production and parental care underlying a suite of life history attributes." At the K end of the continuum, organisms produce very few offspring and invest a large amount of care in each, whereas at the $r$ end, there are many offspring but little or no parental care. This "gene-based theory of reproductive strategies" represents, according to the authors, a trade-off "between gamete production and social behaviors such as intelligence, law abidingness, and parental care." They conclude that populations of "African ancestry are inclined to a greater frequency of uninhibited disorders such as rape and unintended pregnancy and to more sexually transmitted diseases including AIDS."

The preposterousness of their crude sociobiology is probably evident to all but rednecks, but what about my former fellow Harvard professor, the late Richard Herrnstein, who with Charles Murray, ${ }^{11}$ authored The Bell Curve? Herrnstein had advanced the thesis that in a democratic society where there are no barriers to personal achievement, there would inevitably come to be a concentration of superior genes at the top of the social hierarchy. Because few blacks are found at the top in the United States, Herrnstein and Murray concluded the lower academic and intellectual accomplishments of blacks in America are gene-based; differences in life experiences and opportunities contribute, in their view, only a small part of the observed variance. No barriers to personal achievement? Try that one on for size in Chicago housing projects or parts of Harlem where the life expectancy for black male adults is less than it is in Bangladesh! ${ }^{12}$

\section{WHAT DOES COMPLETION OF THE GENOME MEAN?}

As Bruce Korf points out, "the completion of a working draft of the human genome represents a milestone along the road toward understanding the contribution of genetic factors to disease that will transform the practice of medicine."13 Milestone it is, but there is still a long itinerary from the linear DNA code to the controls on methylation of DNA, to the translation of RNA into protein, to the folding of the protein into a three dimensional configuration, to post-translational addition of sugars to the protein backbone, to protein-protein interactions, and so on step after step till we arrive at the phenotype. To borrow Wolfgang Pauli's metaphor, completion of the working draft of the genome is more like providing the frame than completing the portrait. A story is told about Werner Heisenberg. ${ }^{14}$ In the 1930s, he let it be known that he had put together the broad outlines of a theory unifying gravity and electromagnetism and that he would publish it once he had sorted out the details. Pauli, himself a Nobel Laureate with a mordant sense of humor, sent a friend a postcard on which he drew a frame around a blank space and wrote: "This is to show that I can paint like Titian. Only details are missing." Filling in those "details" will occupy molecular geneticists for a while to come.

My point is that we have a long way to go. Go we will but when we get there, where will we be? Will detailed knowledge of the genome foretell the future of our children? In Greek mythology, three figures wove the tapestry of human fate: Lachesis, the measurer, allotted to each his portion; Clotho, the spinner, spun out the threads of life; and Atropos, the lady of the shears, severed the thread at the appointed time. Similar myths abound in other cultures. In the Icelandic sagas, man's fate is determined by the witches, Urdur, Verdandi, and Skuld. Indeed, UVS is the acronym used by an Icelandic biotech startup eager to mine the gene pool of its countrymen. How far do these ancient myths foretell the truth? Are adenine, cytosine, guanine, and uracil the weavers of our fate?

To put the question in these terms is to retreat to Galton's jingle. To ask how much of the phenotype is due to nature and how much to nurture is as profitless as to ask how much of the area of a rectangle is due to its length and how much to its width. Every phenotypic trait reflects the outcome of genes expressed in particular environments. Agreed, there are limiting cases at either extreme; that is, there are lethal genes (mutations incompatible with fetal viability) and environments lethal to every genome. When tons of carbon dioxide erupted from Lake Nyos in the Cameroon on August 21, 1986, the cloud suffocated everything in its path as it rolled down the hill. By next morning, 1700 people and countless animals were dead. ${ }^{15}$ There were no gene-based exceptions. In most clinical circumstances, however, the gene effects we encounter have been modified by the environments the organism has experienced and the environmental effects we see are dependent on the genomes of the organisms they have acted upon.

\section{HERITABILITY IN CONTEXT}

Gene effects may become evident to researchers only after environmental variance has diminished. Barton Childs and Charles Scriver ${ }^{16}$ point out that, when changes in the environment diminish the extrinsic causes of a disease without eliminating that disease altogether, the remaining cases will show a 
larger heritability. Secular changes in the epidemiology of rickets provide a striking example.

Osler's 1901 Textbook of Medicine ${ }^{17}$ described rickets as "particularly marked among the poor of the larger cities," which he attributed to their being "badly housed and ill fed." The discovery of the role of vitamin D in the 1920s, the recognition of the benefits of sunlight and the provision of Denriched milk resulted in a dramatic decrease in the prevalence of rickets among the poor in subsequent decades. That permitted the discovery of inherited defects in vitamin D metabolism, ${ }^{18}$ the genetic signals previously having been unrecognizable against the background of environmental "noise" resulting from phenocopies. ${ }^{19}$ As improved living conditions in industrialized countries removed exogenous causes, the heritability of phenotypic rickets increased from undetectable levels toward one! However, nutritional rickets persists, albeit at a low rate, among breast-fed black American children not on D supplements and insufficiently exposed to sunlight; ${ }^{20}$ osteomalacia and muscle weakness are seen in Denmark among Arab women who cover almost all their skin surface with clothing and in the United States among home-bound elderly patients in the winter, circumstances which result in reduced production of D-3 in the skin. ${ }^{21}$

\section{IDENTICAL GENOMES, DIMORPHIC PHENOTYPES}

Dimorphic phenotypes can arise from identical genomes as evident from the phenomenon of polyphenism; that is, discrete phenotypic classes arising from the same genome. Dimorphic oak caterpillars, for example, express phenotypes so distinct in responding to diet and time of year that the two morphs were initially classified as separate species. The key difference between continuous phenotypic variation and polyphenisms lies in a complex underlying regulatory mechanism controlling a fork between divergent developmental pathways, such as a change in hormone level that intervenes between environmental signal and gene expression. "The expression of a polyphenism begins when [extrinsic] signals are transduced into a developmental switch governed by the interplay of hormone secretion, hormone titer, threshold of sensitivity to the hormone, timing of the hormone-sensitive period, and specific cellular responses to hormones." 22

The honey bee (Apis mellifera) is an illustrative case in point. Female larvae differentiate into queens or workers, despite genomic identity. Larvae that will become queens are reared in large vertically oriented brood cells. As many as a dozen queens may be reared simultaneously (the first to emerge kills the others by stinging them in their cells!). Queens are fed what is termed "royal jelly" by nurse bees. No unique "royal" ingredient has been identified, ${ }^{23}$ but there are consistent differences in the frequency, the amount, and the composition of feedings for queens (the amount is some 10 times as copious). Genetically governed programs add their own effects downstream. Distinct developmental differences in titers of insect terpenoid juvenile hormone and ecdysone become manifest as the growth rate of queens outpaces that of workers. ${ }^{24}$ Sequential studies of gene expression during the development of queens and workers reveal many differentially expressed loci. The phenotypic outcome is morphologically, reproductively, and behaviorally distinct castes. The ballet between genome and socially organized behavior is exquisitely adapted to the environments in which the dance is performed. Abundance of nutrition induces behavior change and polyphenisms in bees and oak caterpillars, as do day length and humidity in aphids and butterflies, and population density and predator presence in other arthropods. ${ }^{25}$

\section{PARENTING AND GENE REGULATION}

The interplay between the genes that govern development in mammals and the social inputs instrumental in that development is most strongly evident in infancy, although it continues throughout life. The dependence of human infants on parenting for sheer survival creates the social context in which we become human. Not only does the growth of the child's social intelligence result from such relationships but so also does the organization of its neuroendocrine axis. The multiple sensory inputs that accompany parenting-warmth, odor, touch, sound, sight, proprioception, vestibular activation—all influence the hypothalamic-pituitary adrenal system. The infant's body temperatures, respiration, and cardiovascular rhythms are regulated by caretakers when they respond to distress signals by holding the infant more closely and feeding it. Infant homeostasis is the outcome of a collaborative process. Maternal touch and warmth modify infant growth hormone production. Pathological interactions between depressed mothers and their infants skew the dyadic relationship.

My colleagues, Maya Carlson and Tony Earls, ${ }^{26}$ have shown that severe social deprivation disrupts neuroendocrine regulation. Waking levels of cortisol in 2-year-old institutionalized children in Romania were significantly lower than in homereared children; cortisol failed to show normal circadian rhythms. Will these unlucky infants and toddlers face longrange neuroendocrine dysfunction and brain pathology? Monkeys reared in social isolation, not only show severe emotional dysregulation as adults but also display hippocampal abnormalities. ${ }^{27}$ Long-term outcomes for the abandoned Romanian orphans will not be known for many years. A report by Michael Rutter and his colleagues ${ }^{28}$ indicates that toddlers removed from the orphanages before the age of 6 months and then adopted in the United Kingdom have shown a remarkable degree of catch-up, despite the severe attrition evident on arrival; those rescued after 6 months continue to show cognitive and emotional defects, although they too have made gains.

How does maternal care translate into the development of the child? There is two-way traffic between genes and behavior. Variations in maternal care regulate gene expression and transmit behavior patterns across generations; genetic variation alters parenting behavior.

Maternal licking, grooming, and nursing behavior (LGN) in rodents is a major determinant of endocrine and behavioral stress responses in offspring. ${ }^{29}$ Adult offspring of high LGN 
mothers are less fearful and show diminished hypothalamicpituitary-adrenal responses to stress. One might suppose that transmission is genetic, because the female offspring of highLGN dams themselves exhibit high-LGN maternal behavior. However, when female pups born to low-LGN dams are crossfostered to high-LGN dams, they become high-LGN with their own pups. Maternal behavior has been transmitted across generations by nongenomic means-if you will, by "culture."

Maternal care regulates gene expression in brain regions controlling stress responses. Pups exposed to high-LGN display increased hippocampal glucocorticoid receptor mRNA expression, higher central benzodiazepine receptor levels in the amygdala, and lower corticotropin-releasing factor mRNA in the paraventricular nucleus of the hypothalamus. Social experience alters long-term gene expression.

A contrasting example is provided by studies of voles, mouselike rodents. ${ }^{30}$ Vole species vary markedly in their social behavior. The prairie vole is social and monogamous; the montane vole is asocial and promiscuous. In the male prairie vole, mating stimulates secretion of the hormone arginine vasopressin (AVP). The release of AVP is associated with pair bonding and paternal care. Does the social behavior result from AVP release? Blockade of the vasopressin receptor V1a in the brain prevents both bonding and parenting responses to mating. Contrariwise, intraventricular injection of AVP increases affiliative behavior.

In contrast, administration of AVP has no effect on the montane vole. ${ }^{30}$ The structure of the genes controlling the V1a receptor in the brain differs in the two species; the montane vole V1a gene lacks a 428 base-pair coding sequence found in the prairie vole gene. Gene structures determine and refract behavior patterns.

\section{THE CHALLENGE OF EFFECTIVE COUNSELING}

Presenting patients with the evidence for the effectiveness of preventive interventions does not in itself change behavior. Repeated randomized clinical trials have demonstrated the substantial benefits from the use of aspirin, beta blockers, statins, the angiotensin-converting enzyme inhibitor ramipril, as well as appropriate diet, smoking cessation, and exercise in reducing the morbidity and mortality associated with coronary heart disease. ${ }^{31}$ Yet, two large patient surveys undertaken in the European Community 3 years apart ${ }^{32,33}$ found little change in smoking behavior, an increase in the prevalence of obesity, and persisting hypertension. Nonadherence is the rule rather than the exception when accustomed lifestyles must be changed even among individuals already ill.

How much greater the challenge in counseling asymptomatic persons whose risk has yet to become manifest. Attempts to convey the meaning of genetic "risk" carry the hazard of distorted parental care when risk is misunderstood to mean destiny. Probabilistic estimates are sophisticated concepts, not easy for most lay persons to understand, especially when language like "the gene for diabetes" is used in common parlance even though there are no genes "for" anything other than a protein structure. Non-insulin-dependent diabetes and obesity are both familial; obesity itself increases risk for diabetes; but whether one or the other or both become manifest in a given individual is a function of diet, exercise, and probably other extrinsic variables, all constrained by material circumstances and culture. ${ }^{34}$

Will patients always or even usually benefit from early identification of a genetic risk for which there is an effective intervention? That is the customary assumption. When it is put to test, the findings are not always reassuring. Consider a Swedish trial of preventive counseling of the mothers of infants with alpha-1-antitrypsin deficiency. The risk for chronic obstructive pulmonary disease in adulthood among antitrypsin-deficient individuals is increased several fold by smoking cigarettes. Thus, counseling their parents should make it possible to reduce the risk of premature death from COPD by advising parents not to smoke (and, thus, avoid exposing their children to secondary smoke inhalation) and to educate the youngsters about the special hazards smoking poses for them.

What actually happened when counseling was provided? In a community trial, Thelin ${ }^{35}$ found that parents did not alter their smoking pattern, despite advice to do so. The one clear consequence of counseling was that the mothers became anxious about the health of their children. Rather than understanding that their children were at risk for disease in later life if exposed to cigarette smoke, the parents had come to view them as already diseased. This happened despite special training for the counselors. More than 40 years ago, Morris Green and Al Solnit ${ }^{36}$ identified what they named "the vulnerable child syndrome," children whose mothers continued to regard them as threatened and fragile well after they had recovered from an episode of serious illness. The preventive intervention had proved to be toxic. What had appeared to be a logical public health intervention had to be abandoned.

In our preoccupation with the complexity of unraveling the genome, we have underestimated the considerable skills required for conveying the results of genetic screening and testing to patients and families. It is not simply an intellectual exercise in information transfer. Predictive genetic tests always contain "a substantial component of uncertainty, not only about whether a specific condition will develop, but also about when it may appear and how severe it will be." 37 Information about risk is highly charged and entangled in a web of family relationships. Patients often don't hear-or at least can't recall accurately-what is said to them. Simply telling patients about their health risks, whether the information is derived from DNA or nongenetic sources, rarely suffices to change behavior. ${ }^{38}$ In planning for the education of generalist and specialist physicians, nurses, and genetic counselors in this era of genetic medicine, equal attention must be paid to cultivating the psychological skill and understanding effective genetic counseling requires. Marteau and Lerman ${ }^{38}$ suggest the need for "a human behavioral change project to ensure that 
applications from the human genome project are realized in practice."

\section{THE PROMISE OF “MEDICINE THROUGH A GENETIC LENS"}

If I have stressed the hazards rather than the enormous promise of "medicine through a genetic lens," 39 it is because you need no pep talks from the likes of me. You are, and should be, enthusiastic about the field you have chosen. Genetic understanding can revolutionize medicine by making it possible for clinicians to tailor diagnosis and treatment to the allelic and environmental individuality of the particular patient in the consulting room, not an average man or woman, not of this or that ethnic stock, not within limits for such and such an age, but this person with a phenotype arising from the life-long interactions between a unique genome with components turned off and on at particular windows of time and a specific sequence of environments. Genetics is the Rosetta stone Archibald Garrod recognized when he identified alkaptonuria as an "inborn error" of metabolism. In his Croonian Lecture, Garrod ${ }^{40}$ quoted William Harvey as having said:

Nature is nowhere more accustomed more openly to display her secret mysteries than in cases where she shows traces of her workings apart from the beaten path; nor is there any better way to advance the proper practice of medicine than to give our minds to the discovery of the usual law of Nature than by careful investigation of cases of rarer forms of disease. For it has been found, in almost all things, that what they contain of useful or applicable is hardly perceived unless we are deprived of them, or they become deranged in some way.

\section{References}

1. Eisenberg L. Mindlessness and brainlessness in psychiatry. Br J Psychiatry 1986;148: 497-508.

2. Eisenberg L. Would cloned humans really be like sheep? N Engl J Med 1999;340:471475.

3. Galton F. English men of science: their nature and nurture. London: Macmillan \& Company, 1874.

4. Pearson K, Moul M. The problem of alien immigration into Great Britain illustrated by an examination of Russian and Polish Jewish children. Ann Eugenics 1925-26;1: 5-127.

5. Kimmelman M. Photography Review. Beauty? Brains? Place your orders. New York Times. February 16, 2001.

6. Stromgren E. Recent history of European psychiatry -ideas, developments and personalities: the Annual Eliot Slater Lecture. Am J Hum Genet 1994;54:405-410.

7. Proctor R. Racial hygiene: Medicine under the Nazis. Cambridge, MA: Harvard University Press, 1988:955, 212, 345.

8. Constantinou M. Forgiveness comes easy for Rev. Jackson. San Francisco Chronicle. January 20, 2001.

9. Abate T. Nobel winner's theories raise uproar in Berkeley. San Francisco Chronicle. November 14, 2000.

10. Rushton JT, Bogaert AF. Population differentials and susceptibility to AIDS: an evolutionary analysis. Soc Sci Med 1989;28:1211-1220.
11. Herrnstein RJ, Murray CA. The bell curve. Intelligence and class structure in American life. New York: Free Press, 1994.

12. McCord C, Freeman HP. Excess mortality in Harlem. N Engl J Med 1990;322:16061607.

13. Korf B. Medicine in transformation -integration of genetics into medical practice. 1997 http://www.humangenetics.org

14. Lindley D. Book review. Nature 2001;410:146.

15. Clark T. Taming Africa's killer lake. Nature 2001;409:554-555.

16. Childs B, Scriver CR. Age at onset and causes of disease. Perspect Biol Med 1986;29: 437-460.

17. Osler W. The Principles and Practice of Medicine. 4th Ed. New York: D. Appleton \& Co., 1901.

18. Albright F, Butler AM, Bloomberg E. Rickets resistant to vitamin D therapy. Am J Dis Child 1937;54:529-547.

19. Eisenberg L. From circumstance to mechanism in pediatrics during the Hopkins Century. Pediatrics 1990;85:42-49.

20. Rowe PM. Why is rickets resurgent in the U.S.? Lancet 2001;357:1100.

21. Holick MF. Sunlight. "D"lemma: risk of skin cancer or bone disease and muscle weakness. Lancet 2001;357:4-5.

22. Evans JD, Wheeler DE. Gene expression and the evolution of polyphenisms. Bioessays 2001;23:62-68.

23. Brouwers EVM, Ebert R, Beetsma J. Behavioural and physiological aspects of nurse bees in relation to the composition of larval food during caste differentiation in the honeybee. J Apicultural Res 1987;26:11-23.

24. Hartfelder K, Engels W. Social insect polymorphism: hormonal regulation of plasticity in development and reproduction in the honeybee. Curr Top Dev Biol 1998; 40:45-77.

25. Evans JD, Wheeler DE. Expression profiles during honey bee caste determination. Genome Biol 2000;2(1) http://genomebiology.com/1000/2/1/research/0001.

26. Carlson M, Earls F. Psychological and neuroendocrinological sequelae of early social deprivation in institutionalized children in Romania. Ann N Y Acad Sci 1997;807: $410-428$.

27. Lupien SH, de Leon M, de Santi S, Convit A, Tarshish C, Nair NP, Thakur M, McEwen BS, Hauger RL, Meaney MJ. Cortisol levels during human aging predict hippocampal atrophy and memory deficits. Nat Neurosci 1998;1:69-73.

28. Rutter M, and the English Romanian Adoptee Study Team. Developmental catchup, and deficit, following adoption after severe global early privation. J Child Psychol Psychiatry 1998;39:465-476.

29. Francis D, DiOrio J, Liu D, Meaney MJ. Nongenomic transmission across generations of maternal behavior and stress responses in the rat. Science 1999;286:11551158.

30. Young LJ, Nilson R, Waymore KG, MacGregor GR, Insel TR. Increased affiliative response to vasopressin in mice expressing the $\mathrm{V}_{1 \mathrm{a}}$ receptor from a monogamous vole. Nature 1999;400:766-768.

31. Cohen JD. ABC's of secondary prevention of CHD: easier said than done. Lancet 2001;357:972-973.

32. EUROASPIRE. A European Society of Cardiology survey of secondary prevention of coronary heart disease: principal results. Eur Heart J 1997;18:1562-1582.

33. EUROASPIRE II. Lifestyle and risk-factor management and use of drug therapies in coronary patients from 15 countries. Eur Heart J 2001;22:554-572.

34. Eisenberg L. Does social medicine still matter in an era of molecular medicine? J Urban Health 1999;76:164-175.

35. Thelin T. Psychological effects of neonatal screening: a study of parents of children at high risk for serious illness in adulthood due to alpha $_{1}$ antitrypsin deficiency. Lund, Sweden; Student Litteratur, 1985.

36. Green M, Solnit AJ. Reactions to the threatened loss of a child: a vulnerable child syndrome. Pediatrics 1964;34:58-66.

37. Evans JP, Skrzynia C, Burke W. The complexities of predictive genetic testing. BMJ 2001;322:1052-1056.

38. Marteau TM, Lerman C. Genetic risk and behavioural change. BMJ 2001;322:10561059.

39. Childs B. Medicine through a genetic lens. In: Eisenberg L, Hager M, editors. The implications of genetics for health professional education. New York: Josiah Macy, Jr Foundation, 1999:27-51.

40. Garrod A. The lessons of rare maladies. Lancet 1928;1:1055-1060. 